\title{
Understanding the Aspects of Forming Components of the Public Service Bargains Concept
}

\author{
$1^{\text {st }}$ Yetty Setiyaningsih, $2^{\text {nd }}$ Agus Pramusinto, $3^{\text {th }}$ Bevaola Kusumasari, $4^{\text {th }}$ Yuyun Purbokusumo \\ \{yetty.setiyaningsih@mail.ugm.ac.id ${ }^{1}$, aguspramusinto@ugm.ac.id ${ }^{2}$, bevaola@ugm.ac.id $^{3}$, \\ yuyun@ugm.ac.id $\left.{ }^{4}\right\}$ \\ Phd Student at Department of Public Policy Management, Gadjah Mada University \\ Yogyakarta $^{1}$ \\ Lecturer at Department of Public Policy Management, Gadjah Mada University Yogyakarta ${ }^{2,3,4}$
}

\begin{abstract}
In bureaucratic interaction with its socio-political environment, bureaucracy must be involved in a variety of different types of political behavior, both to maintain its autonomy as an organization that impacts on public policy. One way to focus on the relationship between bureaucracy and the social or political environment is to explore the types of agreements between the bureaucracy and the socio-political environment or public service bargaining that occurs in between. The implementation of this research comes in the background of thinking the need to open a discussion for the concept of Public Service Bargains (PSB) from Hood and Lodge (2006) which is more comprehensive and contextual from the standpoint of existing theoretical practice. This paper discusses what aspects make up the PSB component. Academically, the importance of this research is to find out the aspects of PSB component formation, so that it will be more helpful in analyzing the types of PSB in policy studies. This study uses a qualitative descriptive approach and uses a variety of reference sources taken from research related libraries by analyzing the components of PSB. The hope of the findings of this study is that the results of the research will contribute to the process of government policy making by providing definitions that are in line with the initial conceptions of the PSB concept. Therefore, this research is expected to contribute to the development of policy studies
\end{abstract}

Keywords: Public Service Bargains; Public Policy Management; Bargain.

\section{Introduction}

This study examines the PSB concept put forward by Hood and Lodge (2006). Although there have been many studies carried out related to this concept, such as those in the Netherlands, England, Canada, Belgium and Germany about differences in bureaucratic performance management systems, the history of a country's administration, including the traditional relationship between politicians and administrations determining the type of PSB [1],. In Belgium, reforms in the government have changed the type of PSB in the relationship between ministers and secretary generals [1] as well as in Estonia and Denmark the application of the New Public Management has changed the type of PSB in the country. About the role of PSB in the placement of senior officials in the bureaucracy in Europe. The dynamics of the PSB can also be explained by changes in position within the ministry and the interests of political actors. In non-European countries [2] examined the utility of public service frameworks in nonEuropean settings, namely Hong Kong, to better understand the extent to which the PSB theory 
goes well outside Europe. But there is no research that discusses what aspects make up the PSB component. As stated by [3] that PSB consists of 3 (three) components, namely reward, competence and loyalty. This research is important because by knowing the aspects of PSB forming components, it will be easier to analyze PSB forming components. The purpose of this article is to open a discussion for a more comprehensive and contextual concept of PSB that takes into consideration theoretical perspective.

\section{Methodology}

With this study the authors intend to provide a literature review for the concept of PSB [3] ,primarily in understanding what aspects make up the PSB component. The concept of Hood and Lodge (2016) is more comprehensive and contextual from the standpoint of existing theoretical practice. [4], despite the basic idea of PSB from Schaffer (1973). This research used a descriptive qualitative method to understand the concept of PSB. Data was collected using library research, which was supplemented by a strategic review of documents on the implementation of PSB in a number of studies.

Stage 1 : Data Source

Understand the definitions and concepts of PSB Hood and Lodge (2006) by carried out with an in-depth study of these concepts and their initial ideas and origins. Then subsequently undertake a PSB review in various countries, to see how PSB is implemented in various countries from previous studies and literature studies.

\section{Stage 2 : Develop a Theoretical Framework}

This is done by analyzing the application of PSB in various countries from previous studies and analyzing the relationship of the concept of Hood and Lodge (2006) with relevant theories. In this stage an in-depth analysis of the PSB components is carried out.

\section{Stage 3 : Analysis And Presentation Of Results}

In this stage, an in-depth analysis of the framework for knowing the relationship between theory, aspects that are formed and components in the PSB so as to produce aspects that form the components of the PSB

\section{Finding and Discussion Definition and Concept of Public Service Bargains}

The Public Service Bargain (PSB) concept [3], is a concept by facilitating the operationalization of changes in the public sector service system. PSB is defined as "any explicit or implicit understanding between civil servants and other actors in the political system of their duties and rights relating to political responsibility, autonomy and identity, and expressed in formal conventions or laws or a mixture of the two"[3] . According to the PSB concept, politicaladministrative relations are based on implicit or explicit bargaining between the two parties where, in simple terms, political authorities expect competence and loyalty from civil servants and later expect some mixed rewards (both tangible and intangible) and autonomy in certain areas of responsibility in return[2][3]. PSB can be formally stipulated in the constitution, laws, civil service law and code of ethics (systemic PSB) or informal understanding between actors involved in bargaining as reflected in expectations of a normative role (pragmatic PSB) as stated. 
The next concept was further developed by [3]Hood and Lodge describe politicaladministrative relations as an implicit or explicit bargain in which politicians get some level of loyalty and competence from civil servants, and civil servants get a place in the structure of government, responsibilities and rewards. With the concept of bargaining, they build on indications [5] of understanding between elected politicians and appointed bureaucrats as developed in England during the nineteenth century. [6] and [3] establish the typology of public service bargaining, because they identify Schaffer bargaining as only one of several types of offers available. In PSB according to [3] politicians usually expect to obtain some level of loyalty and political competence from bureaucrats or civil servants, and civil servants usually expect to get a secure place in the structure of the executive government, a scope of responsibility that's certain and some tangible mixture. and intangible gifts. Politicians often give up some of their rights to employ, do, reward, or even direct civil servants at will, and civil servants often give up some of their rights to blame or express political opposition to the ruling regime. Political loyalty in some form is usually exchanged with the wisdom of public servants.

The concept of public service bargaining takes into account how a number of institutional aspects impact power relations between actors. This makes it possible to illustrate the different impacts of the political-administrative tradition on the positions and roles of prominent civil servants in various countries [1]As such, the typology of public service bargaining is a useful tool for comparative research. Characteristics of existing public service bargains can help shape the impact of administrative reform on the roles and positions of leading civil servants today (Hondeghem, Changing public service bargains for top officials, 2011). As indicated [3]public service bargaining may also differ in the extent to which they leave room to maneuver for prominent civil servants to act strategically. Characteristics of public service bargaining will have an impact on the opportunities available to reform public [6]bargaining of public services itself is also influenced by public sector reforms.

In [3]PSB has 3 (three) aspects, namely rewards, competencies and responsibilities or loyalty. The reward aspect relates to what civil servants receive in return for their hard work, in what form and at what stage in their careers. The politics of civil servants who reward and manage their careers has been the heart of much debate. The dimensions associated with gifts affect tangible and intangible rewards, including salaries and pensions, expectations regarding career advancement, and the level of permanence of positions or risks of dismissal. The aspects of PSB competence are related to what is expected to be known or done by civil servants. New demands on competence have been made on civil servants in many political systems in the past, with the capacity for policy making to be needed from some executive public services to date and managerial capacity needed from public services that have so far focused on policy. The aspect of responsibility relates to matters in which civil servants have an autonomous decision making power compared to politicians, compared to those who are considered as agents or carriers of simple bags.

Overall, PSB has a perspective on executive governance that combines a comparative or historical analysis of the political system with a perspective of strategic action on making, terminating, and maintaining agreements between bureaucrats and actors in politics [3]

\section{Overview of Public Service Bargains in Various Country}

As explained in [3] that PSB can vary greatly both in domains and in systems that change and are dynamic over time and the traditions of each country are different. In the Netherlands, Denmark, England, Canada, Estonia and Hong Kong who adopt a parliamentary system of government have different types of PSB. In the Netherlands the highest position of civil servant is the secretary general while in Denmark, Britain and Hong Kong are permanent 
secretaries while in Canada and Estonia, respectively are deputy ministers and heads of departments. In the Netherlands Century 18-19 adopted the PSB consociational bargain. In 1995 shifted to Managerial PSB with ABD (Algemene BestuursDienst) [7]PSB research on new hybrid types has emerged; which includes the aspirations of manageralization and professionalization, and (re) affirmation of political priorities. While in Denmark,

The existence of the reform movement through NPM has influenced the role of the permanent secretary but does not change / replace the existing PSB which is the hybrid type. PSB in Denmark most closely resembles Hybrid type PSB [1]The type of PSB in UK is Schaferrian but has evolved towards hybrid PSB. In the terms of system performance, PSB in the UK is a strong managerial type.

PSB types in Canada are Schafferian, hybrid and negotiative mixed types ([1].In terms of PSB management performance systems in Canada it is a strong managerial type. In the year of (19962012) PSB in Estonia is a pargamic type PSB with a hybrid subtype with PSB components ; Reward: A mixture of pyramid and Turkey Race forms, Competency / Deliverers, Loyalty: Partnership.Since 2013 due to the influence of NPM into a moderate managerial pragmatic PSB with a hybrid subtype with a PSB component ; Reward / prize: Turkey Race, Competency / Deliverers, Loyalty: A mixture of partnership and executive type. The PSB that developed in Hong Kong today is a pragmatic hybrid typology as a result of changes in governance and Hong Kong's status as part of the RRC. There was a PSB evolution from trustee typology to agency typology during the colonial era [3] because most 'Ministers' were retired civil servants.

\section{PSB Components}

Public service bargaining varies across three components: rewards, competence and loyalty [3]Component definitions may be different, and their relative weights in PSB [3]. For each component, [3] have developed a different typology, based on grid-group theory.

Table 1.Type Of PSB Components

\begin{tabular}{cc}
\hline Components & Type \\
\hline & Pyramid \\
Reward & Noblesse Oblige \\
& Turkey Race \\
& Lottery Of Life \\
\hline \multirow{2}{*}{ Competency } & Wonks \\
& Deliverer \\
& Sage \\
Loyalty & Go between \\
\hline & Judge \\
& Partner \\
Excecutive \\
Jester
\end{tabular}

Source : Hood and Lodge (2006)

The first component of PSB is reward explaining what civil servants receive in return for their contribution [3]. [3]identified four types of prize bargains: the "pyramid" or "elevator" type, "noblesse oblige", "turkey race", and "life lottery". The type of prize "pyramid" or "elevator" includes a hierarchy of structured rewards in the hope of an orderly and predictable development. "Noblesse oblige" or "rent non-seeking" contains the relative restraint of salaries 
in the ranks of civil servants in return for honor and social respect that comes with high status and inner satisfaction. "Turkish race" bargaining means that there is an agreement in which prizes are based on individual competition and variable prizes play an important role. "Lottery of life" bargaining involves rewards that are not automatic or unpredictable, sometimes depending on luck and opportunity, and rewards that are relatively independent of individual skill, desert, or intelligence. "managerial age" at the end of the 20th century is said to have challenged many traditional award patterns. As a consequence of NPM reforms accompanied by an aging population and scal consolidation [3]there has been a general decline in monetary rewards, decreases in pensions, and increases in retirement age. As a result, in managerial PSB, prizes are characterized by less permanent, lateral entry, competition for promotion, competitive performance and salary related. This can be described as a type of "turkey race" PSB. Post-NPM is expected to lead to a reduction in the extent to which performance payments are provided and in a distributed manner, specifically moving from individuals to a team-based incentive system.

The second component of PSB is competency, which refers to key aspects related to professionalization in terms of the qualifications and skills required, the appointment process and training. Although competence can be seen as one of the most important criteria in a modern meritocratic civil service system [8]the relative substance and weight of different competency requirements can vary across states, organizations, jobs or preferences of a single manager [3].[3]describe four types of competency offerings: "wonks", "go-betweens and brokers", "deliverers", and "sage". In bargaining "wonks", civil servants can govern certain fields where they have technical skills. Similar to "wonks" bargaining is "go-betweens and brokers" bargaining, which emphasizes the ability of public servants to unite different "worlds", acting as facilitators, brokers, diplomats, or go-betweens rather than operating in chains command. refers to the ability of civil servants related to political expertise. Unlike the "wonkish" and "spanning" competencies, the core of "delivery" or competence bargaining lies in the ability of individuals or skills to be able to make updates in a government organization rather than just following rules or routines [3]"Sage" competence is to provide intellectual or moral insight rather than to rule or make agreements between groups. This assumes that official knowledge comes from innate qualities and experiences and cannot be easily taught at universities such as the ability to identify and assess political risks intuitively. Managerial PSB is more like the type of "sender" PSB because managerial skills are considered more important than technical skills, and in line with managerial approaches, outcome orientation is highly valued. According to, the main difference between NPM age and post-NPM age lies in the competency dimension: whereas the NPM type PSB emphasizes the importance of "delivery" in one organization (justified by the notion of "focus" and "specialization"), ideas the underlying competencies represented in the post-NPM literature emphasize the importance of boundaries and collaboration.

The third component of PSB is related to responsibility and loyalty with the level of autonomy of civil servant decision making compared to politicians. This can be more important than competence for PSB parties [3]. On the one hand, civil servants are expected to be loyal to the state, the public interest, and the government as an institution; on the other hand. Conversely, politicians expect civil servants to be committed to their political goals (serial loyalists) or certain ministers (personal loyalists) [3] These two potentially conflicting expectations can lead to various conflicts of loyalty in the relationship between politicians and public servants, and ultimately towards the politicization of civil services [9]There are four types of loyal offers: "jury", "partnership", "executive", and "jester" types [3] In the "judge" bargaining type, civil servants show loyalty to the state and the law, and they act as semi-autonomous players with 
loyalty to higher entities partially or wholly interpreted by themselves - departments, laws, constitutions, public interests, citizens, and others.

At the opposite pole of the "judicial" bargain comes the offer of "partnership", where civil servants work together with elected politicians but do not have separate identities, either in directing public organizations or in determining policies. Such arrangements mainly apply to so-called "loyalists", whether "personal" (hybrid type bargaining) or "series" (Schafferian type bargaining) [3]By bargaining for "executive" loyalty, bureaucrats can separately be identified as individuals but not free agents in a political sense - they pursue goals that are determined in a limited and irrevocable space of action. In bargaining for the loyalty of the "jester" type, certain individuals are given rights within a number of restrictions that are usually not determined to operate as reality checkers for the authorities. Managerial PSB is a type of "executive" PSB because loyalty is expected primarily to the leader in charge, performance can be defined in individual performance agreements subject to strict strict controls. Politically, liability is not a problem, because management is considered a neutral issue. If a failure occurs, the error is in the manager. In short, the civil service system can be understood as an interdependent complementary system or dimension. Any reform on one dimension will have a direct impact on other aspects of the bargain. For example, the pursuit of prizes will have implications not only in terms of motivation, but also in loyalty and competence.

\section{Theoretical Framework for the Concept of PSB}

This research begins with the thought that in the interaction of bureaucracy with its socio-political environment, bureaucracy must be involved in different types of political behavior, both to maintain its autonomy as an organization that impacts on public policy [9]In its interactions, as an organization in making decisions, power and power are used to get the desired results [10]In this case the political behavior of the bureaucracy as a system in managing resources has a contradictory tenden\$cy but also aims to achieve harmony ([8]\In realizing harmony in determining the output of this policy PSB offers a new concept so that an alignment is achieved in a policy output and especially in a crucial policy that is the budget determination policy [11]The theoretical framework can be seen in the following figure. 
Power and Politics OrganizationTheory

Decision power (Pfeffer, 1982)
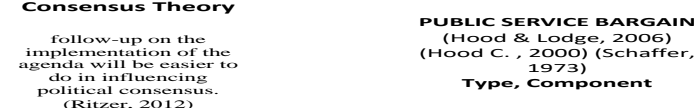

Type, 1973$)$

Conflict Theory

(Ritzer, 2012)
(Ritions cons

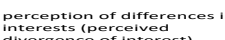

divergence of intere

(Dahrendorf., 1981

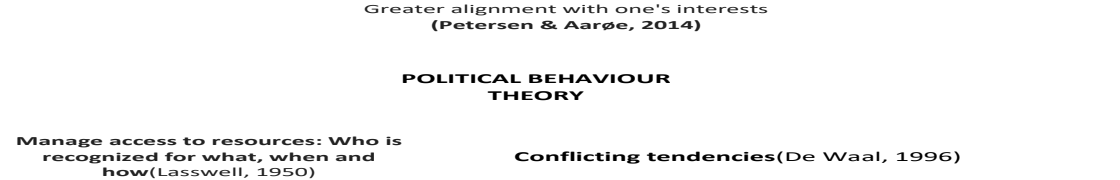

Figure 1. Theoritical Framework

Source: Review of Literature (research)

\section{Theory Relevant to Public Service Bargains}

\section{Principal - Agent Theory (Jensen-Meckling)}

Agency relations occur because of an agreement or contract made by the principal and agent. Principal gives a job to the manager to be able to take the best decision for the principal. But the agent must be able to account for the decisions that have been taken. Often the objectives of shareholders differ (agents) with the objectives of the manager (principal), but if the principal and agent have the same goal to maximize utility, the agent will take action in accordance with the interests of the principal [12]

[13] put forward agency theory by explaining that the interests of management and the interests of shareholders are often in conflict, so that it can cause conflicts between the two. This happens because managers often prioritize personal interests. Shareholders do not like the interests of managers, because it can add costs to the company so that it will reduce the profits received. Shareholders prefer these costs to be financed by high-risk debt, while managers are more likely to want these costs to be financed from internal funding sources within the company, because internal funding sources only have a lower risk than external funding sources. Having these two interests different will create problems between shareholders and managers[13]argues that conflicts of interest between managers and shareholders can be minimized by a monitoring mechanism that can align these related interests, so with the existence of this oversight mechanism, a fee is called agency costs. 


\section{Theory of Power and Politics Organization}

The role of power in decision making Most definitions include elements which state that power is the ability of a social actor to overcome resistance in achieving desired goals. Power is defined as strength; power given from one actor to another. Legitimacy is defined as a series of activities that are received and expected. Therefore the strength that is received and expected to be an authority. Preference (whether willing or unwilling) for such power procedures reinforces the concept of authority. They become defined as activities where power is used to obtain certain catalogs of desired results. Usually, in situations where politics is used or seen, trust is widespread. Understanding the role of power in decision making is a basic contribution to the Theory of Political Organization and Power. Strength is the ability to get things done the way they want; it is a latent ability to influence people. This definition offers several advantages for understanding an organization. Power is a specific context or relationship. Someone is generally not strong or helpless, but only with respect to other social actors in certain relationships. This is important because strength is primarily a structural phenomenon, a consequence of division of labor and specialization [14]

\section{Political Behaviour Theory}

Political behaviour is behaviour aimed at regulating access to resources: Who is recognized for what, when and how If social behavior is about playing a game, political behavior is about determining the rules of the game being played. For example, while many social animals can exercise together, only political animals can negotiate and change the rules governing the surplus that flows from this exercise. Humans are political animals like that but other species are also political. Basically, each species with conflicting interests and cognitive capacities for what is called is called a sense of political order. Conflicts of interest are the main drivers of political behavior and a sense of social order is the main target of political behavior. Thus political behavior is behavior that seeks to uphold one's interests by encouraging a sense of order that is shared together into greater harmony with one's interests [8]

\section{The Linkage of Theory and Concept of PSB Components}

As explained in the theoretical framework that the PSB component is formed from 3 (three) aspects, namely aspects of interaction, power and behavior. The interrelated theories, aspects that form the components of the PSB can be explained in table 2.

Table 2.The Linkage of Theory and Concept of PSB Components

\begin{tabular}{|c|c|c|c|}
\hline & Theory & Aspect & Components \\
\hline $\begin{array}{l}\text { Conflict Theory } \\
\text { (Dahrendqrf., 1981) }\end{array}$ & $\begin{array}{l}\text { Perception about differences in } \\
\text { interests }\end{array}$ & & \\
\hline \multirow[t]{2}{*}{$\begin{array}{l}\text { Consensus Theory } \\
\text { (Ritzer,2012) }\end{array}$} & $\begin{array}{l}\text { Follow-up on the implementation } \\
\text { of the agenda will be easier to do in } \\
\text { influencing political consensus }\end{array}$ & & \\
\hline & & Interaction Aspect & Reward \\
\hline $\begin{array}{l}\text { Symbolic } \\
\text { Interactionism Theory } \\
\text { (Blumer,1969) }\end{array}$ & $\begin{array}{l}\text { The role of communication in } \\
\text { forming and managing } \\
\text { interpersonal relationships and } \\
\text { social groups }\end{array}$ & & \\
\hline
\end{tabular}




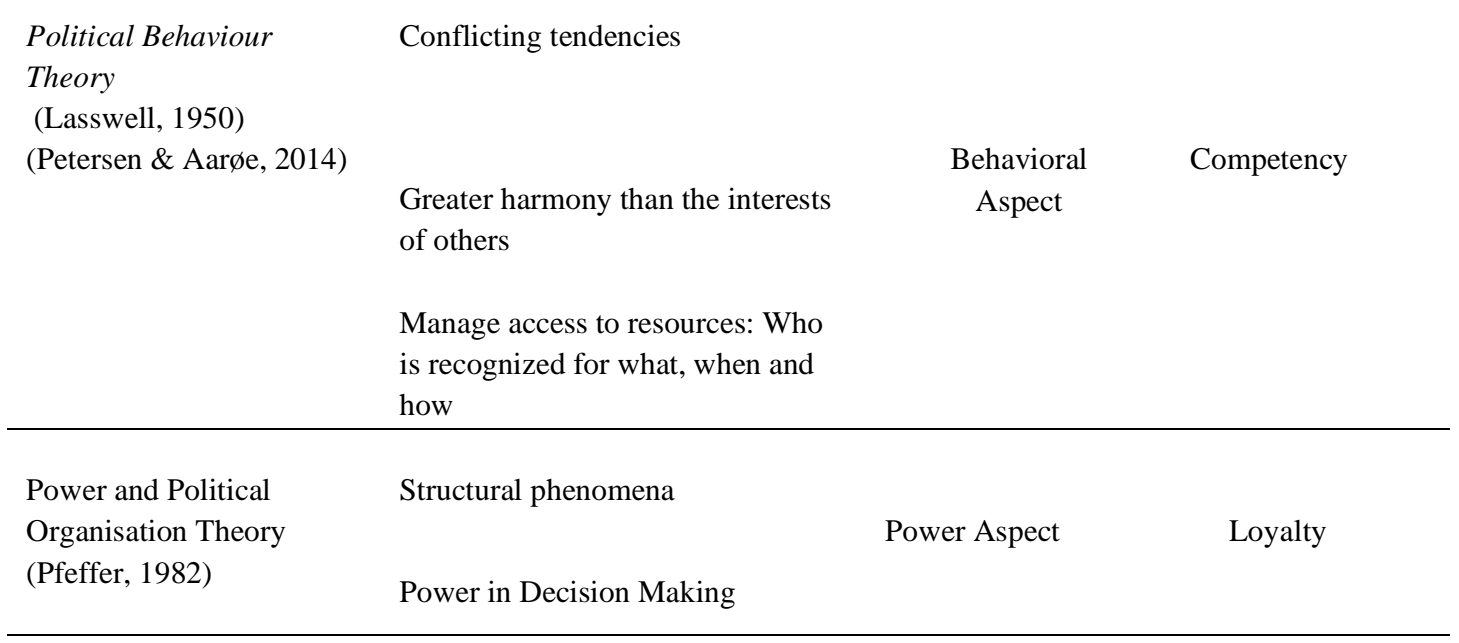

\section{Source: Review of Literature (research)}

Reward as stated by Hood and Lodge (2006) is what civil servants receive in return for their contribution. The difference in interests or perceptions triggers a conflict (Dahrendarf, 1981), with these differences in interests both bureaucrats and politicians need an agreement (bargain) so as to produce a consensus so that the implementation of the next agenda is easier (Ritzer, 2012). In this case the need for a communication in forming and managing interpersonal relationships and social groups (Blumer, 1969). In this connection it becomes an interaction between politicians and bureaucrats, and what is given by bureaucrats get compensation from politicians for a mutual agreement between the two.

The second component of PSB is competence, which refers to the key aspects related to professionalization in terms of the qualifications and skills needed, the process of appointment and training. In this case conflicting tendencies (Laswell, 1950) occur where there is a tendency for political behavior to achieve greater harmony greater than one-sided interests (Petersen \& Aarøe, 2014). Political behavior regulates access to resources who is recognized as getting what, when and how (Petersen \& Aarøe, 2014), this is where the behavioral aspects form competencies, which are abilities and skills in the concept of PSB.

The existence of structural phenomena in bureaucracy, as well as power in decision making in the theory of power and organizational politics, is an aspect of power in a bureaucrat's interaction with its political environment and forms loyalty or submission. Loyalty in the PSB is the level of autonomy of civil servants decision making compared to politician.

\section{Conclusion}

This research has produced several formulations. First, that PSB components are formed and influenced by 3 (three) aspects, namely aspects of interaction, aspects of behavior and aspects of power. Second, each aspect forms a component in the PSB, namely the interaction aspect forms the reward component, the behavioral aspect forms the competency component and the power aspect forms the loyalty component. Third, knowing the aspects of the PSB component, becoming a new contribution to the PSB theory, and in determining a policy, will 
make it easier to analyze the type of PSB. The findings of this research also further clarify the definition of the PSB component put forward by (Hood and Lodge, 2006)

\section{References}

[1] A. Hondeghem and K. Van Dorpe, "Performance Management Systems for Senior Civil Servants: How Strong Is the Managerial Public Service Bargain?," Int. Rev. Adm. Sci., pp. 9-27, 2013.

[2] J. P. Burns, L. Wei, and B. G. Peters, "Changing governance structures and the evolution of public service bargains in Hong Kong," Int. Rev. Adm. Sci., vol. 79, no. 1, pp. 131148, 2013.

[3] C. Hood and M. Lodge, The politics of public service bargains: Reward, competency, loyalty-and blame. Oxford University Press on Demand, 2006.

[4] G. Helmke and S. Levitsky, "Informal institutions and comparative politics: A research agenda," Perspect. Polit., vol. 2, no. 4, pp. 725-740, 2004.

[5] J. D. Aberbach and etc., Bureaucrats and politicians in western democracies. London, England: Harvard University Press, 1990.

[6] C. Hood, "Paradoxes of public-sector managerialism, old public management and public service bargains," Int. public Manag. J., vol. 3, no. 1, pp. 1-22, 2000.

[7] M. B. Hansen, T. Steen, and M. D. Jong, "New Public Management, Public Service Bargains and the challenges of interdepartmental coordination: a comparative analysis of top civil servants in state administration," Int. Rev. Adm. Sci., vol. 79, no. 1, pp. 29 48, 2013.

[8] M. B. Petersen and L. Aarøe, Evolutionary Theory and Political Behavior. Denmark: Wiley Publishing, 2014.

[9] B. G. Peters and G. Peters, Politics of bureaucracy, 5th ed. London, England: Routledge, 2002.

[10] K. E. Weick, "No Title," Am. J. Sociol., vol. 88, no. 3, pp. 605-608, [Online]. Available: http://www.jstor.org/stable/2779127.

[11] J. Quiggin, Economic constraints on public policy. Oxford University Press, 2008.

[12] Hendrikson, Teori Akuntansi. Jakarta: Penerbit Erlangga, 2000.

[13] M. C. Jensen and W. H. Meckling, "Theory of the Firm: Managerial Behavior, Agency Costs and Ownership Structure," J. Financ., pp. 305-360, 1976.

[14] J. M. Shafritz, J. S. Ott, and Y. Jang, Classics of Organization Theory, 6th ed. Belmont, CA: Wadsworth, 2005. 